\title{
Emigracja, kolonizacja, antropofagia w kontekście „gorączki brazylijskiej”"
}

Emigration, Colonization, and Anthropophagy in the Context of the "Brazilian Fever" W okresie dominacji krajów Europy Środkowej przez ościenne mocarstwa w XIX i początkach XX wieku, noszącej wszelkie znamiona kolonialnego zawłaszczenia, dochodzi do masowych ruchów emigracyjnych, będących sposobem na przetrwanie, zachowanie własnej tożsamości, formą oporu, a zarazem mniej lub bardziej uświadamianą i sterowaną akcją „kolonizacyjną” zamorskich ziem $^{2}$. Kolonizacyjną w cudzysłowie, bo nie nastawioną na zdobywanie kolonii, zawładnięcie cudzą własnością, eksterminację ludów tubylczych, ale na wejście się w cudzą przestrzeń, jej adopcję, kultywację cudzej ziemi w celu przetrwania. Jakże inaczej w porównaniu z europejskimi imperiami kolonialnymi zawłaszczającymi i eksploatującymi cudze ziemie, a wobec rdzennej ludności niecofających się przed praktyką ludobójstwa w celu pomnażania własnego bogactwa. Epopeja kolonizacyjna wydziedziczonych mas chłopskich Europy Środkowej szukających ocalenia przed nędzą i zniewoleniem nie miała przecież nic wspólnego z kolonializmem (jakkolwiek istniały próby wykorzystania jej i do takich celów), ale też z punktu widzenia mieszkańców i kultury

1 Pierwotna wersja tego tekstu była prezentowana na sympozjum „Unforeseen Constellations: Reading Postcolonial Poland with South America” w Polish Studies Center at the University of Indiana in Bloomington, w dniach 28-29 kwietnia 2017 roku.

${ }^{2}$ Miarą kolonialnego zawłaszczenia może być na przykład konfiskata tysięcy listów emigrantów z Brazylii i Stanów Zjednoczonych przez carską cenzurę, a odkrytych w roku 1941 przez Witolda Kulę w podziemiach Archiwum Akt Dawnych w Warszawie. „Zadierżat” wypisane przez cenzora na każdym z tych listów stanowiło akt unicestwienia tego, co w międzyludzkich relacjach najcenniejsze, w imię zachowania absolutnej i uprzedmiotowiającej dominacji nad drugim człowiekiem. Jak pisze Kula: „żaden z listów, które trafiły do piwnicznej skrzyni (...), nie doszedł do adresatów. (...) Małżeństwa rozbite, zaufanie braterskie zawiedzione, rodzice przed śmiercią nie pożegnani” (tenże, Listy emigrantów z Brazylii i Stanów Zjednoczonych, s. 15-16). 
krajów docelowych emigracji mogła nosić jego znamiona i prowokować reakcje obronne.

W masowej emigracji chłopskiej z ziem polskich do Brazylii, która nie bez powodu zyskała nazwę „gorączki brazylijskiej”, uwidaczniają się dwa rodzaje relacji międzykulturowych, które można określić jako kolonizacja i antropofagia. Kolonizacja - w sensie adopcji cudzej ziemi w celu kultywacji służącej przetrwaniu i zachowaniu własnej tożsamości. Antropofagia w znaczeniu nadanym temu pojęciu w okresie brazylijskiego modernizmu, ale odniesiona tu do sposobu, w jaki Brazylia przyjmowała chłopskich imigrantów.

Rozumiana jako rytualne spożywanie ciała wroga, nie dla zaspokojenia głodu, jak w praktykach kanibalizmu, ale po to, by przejąć jego życiodajne, duchowe moce, antropofagia staje się w brazylijskim modernizmie rodzajem antykolonialnej strategii oporu i figurą takich międzykulturowych relacji, w których poddany sile dominacji innej kultury nie tylko broni swej tożsamości, ale także wzbogaca ją, przejmując od kolonizatora jedynie to, co do tego wzbogacenia jest mu jako tworzywo czy też narzędzie przydatne. Oswald de Andrade, jeden z głównych promotorów brazylijskiego ruchu antropofagicznego, postulował asymilację, „pożarcie” nowoczesnej techniki jako jedynej wartości cywilizacji europejskiej, przydatnej w tworzeniu nowej cywilizacji Ameryki. W ten sposób technika miała być „zhumanizowana” i służyć proliferacji życia, twórczości i niczym nieskrępowanej wolności. Mimo iż ruch antropofagiczny odegrał istotną rolę w umacnianiu się brazylijskiej tożsamości w jestestwie swoim, trudno nie dostrzec, że rola ta miała charakter dwuznaczny. Jego przedstawiciele, potomkowie również europejskich kolonizatorów, promowali przecież także rodzaj postawy kolonialnej, à rebours, a choć woleli przemawiać w imieniu ludów tubylczych, brali za dobrą monetę europejski stereotyp „dobrego dzikusa”. Podczas gdy w Europie stereotyp ten służył przeważnie autodeprecjacji czy autokrytyce przy idealizacji Innego, w Ameryce stawał się budulcem nacjonalistycznego samozadowolenia i agresywnego, antyeuropejskiego resentymentu. Nie bez powodu wśród głosów dyskusji toczonej w Brazylii przy okazji obchodów jej 500. rocznicy były i takie, jak socjologa Sergia Paula Rouaneta: „Musimy uwolnić się od mitu dobrego dzikusa. Pięćsetlecie odkrycia Brazylii to dobra okazja do przeprowadzenia takich egzorcyzmów"3.

Strategia antropofagiczna jako rodzaj relacji międzykulturowych może wchodzić w grę, gdy kolonizator przedstawia sobą pewne wartości atrakcyjne dla kolonizowanego, który potrafi stawić mu czoła i wartości te przejąć, by wzbogacić i wzmocnić się nimi w konfrontacji z zagrożeniem, jakie kolonizacja stanowi dla jego egzystencji. W przypadku chłopa polskiego zaborca na ogół nie reprezentował atrakcyjnych dla niego wartości, cywilizacyjnych ani duchowych, a zarazem zbyt wielka była dysproporcja siły, by pańszczyźniany

3 S.P. Rouanet, $O$ mito do bom selvagem [w:] A. Novaes, A outra margem do Ocidente, São Paulo 1999, s. 437. Tłumaczenie przywoływanych fragmentów tekstów - H.S. 
czy semipańszczyźniany chłop mógł skutecznie mu się przeciwstawić. Podobnie było $\mathrm{w}$ jego relacji poddaństwa $\mathrm{z}$ rodzimym właścicielem ziemskim. Dlatego też emigracja zawierająca obietnicę wyzwolenia z poddaństwa i nędzy stała się tak atrakcyjna i na tak wielką rozwinęła się skalę. Emigrant, osadnik, mógł wejść i wchodził w rolę kolonisty, jaką otrzymał od państwa ukształtowanego i rozwijającego się w procesie kolonizacji i w tym procesie szukającego nie tyle sprzymierzeńca, partnera do podziału łupów i dóbr, ile najemnej siły roboczej, służącej konsolidacji władzy i panowaniu nad olbrzymim, zdobytym przez europejskich przodków wcale nie bezpańskim terytorium. Imigrant, osadnik, przy całym swoim heroizmie, determinacji, trudzie, dumie (ale i często zadufaniu) przedstawiciela „wyższej” i „prawdziwie chrześcijańskiej” cywilizacji, pan własnego losu i podmiot projektu kolonizacji (kolonista), był zarazem przedmiotem antropofagicznej strategii państwa brazylijskiego.

Zniesienie niewolnictwa w Brazylii w 1888 roku stwarza zapotrzebowanie na siłę roboczą do produkcji rolnej, które staje się szansą dla żyjących w nędzy mas chłopskich Europy Środkowej. Tak też, jako siła robocza, imigranci są akceptowani, w tym również jako stosujący bardziej zaawansowane technologie uprawy roli, hodowli i transportu. Zainteresowanie ich odmiennością kulturową jest niewielkie, żyją izolowani w enklawach zwanych koloniami, nie brak uprzedzeń rodzących krzywdzące stereotypy. Nieprzypadkowo brazylijski socjolog Octavio Ianni w swym dziele Raças e classes sociais no Brasil (1972) cytuje znamienne powiedzenie „O negro do Paraná é o polaco” („Murzynem Parany jest Polak"), a jego stosunek do polskiego imigranta stawiającego opór procesom asymilacji, ani Brazylijczyka, ani „prawdziwego” Europejczyka, nie jest wolny od uprzedzeń ${ }^{4}$. Proces asymilacji i integracji ze społeczeństwem brazylijskim będzie przebiegał powoli, ale też wielokulturowość stanie się z czasem coraz bardziej cenioną cechą brazylijskiej tożsamości. Znamienna jest na przykład publikacja w ramach obchodu 500. rocznicy odkrycia Brazylii książki zbiorowej pt. República das etnias (2000) ${ }^{5}$, w której przedstawiony został wkład wielu kultur i narodów, wśród nich polskiego, do rozwoju kraju i kształtowania jego kultury.

Etos polskiego kolonisty w Brazylii w konfrontacji z zastaną rzeczywistością i rolą, jaka została mu w niej przypisana, określają takie postawy, jak sakralny stosunek do ziemi i nacechowany ksenofobią stosunek do społeczności tubylczej. Widać to w wielu świadectwach literackich tej chłopskiej odysei, w tym szczególnie w jednym z najbardziej znaczących utworów, jakim jest Pan Balcer $w$ Brazylii Marii Konopnickiej ${ }^{6}$. Sakralny stosunek do ziemi wiąże się z całym kompleksem wiary i rytuału i przeciwstawiany jest bezdusznej jej eksploatacji u tubylców:

\footnotetext{
${ }^{4}$ O. Ianni, Raças e classes sociais no Brasil, Rio de Janeiro 1972.

República das etnias, red. P. Reis, Rio de Janeiro 2000.

${ }^{6}$ M. Konopnicka, Pan Balcer w Brazylii, Warszawa 1910.
} 
Wy kraje swoje macie jak kopalnie,

Dopóki jasna świeci wam z nich ruda,

Póty się sami dmiecie tryumfalnie,

Jak nie, - obcego napędzacie luda...

My do ziem naszych bierzemy się mszalnie,

Krzyżem znaczona jest wiosenna gruda,

A zaś wychodzi z pod tej chłopskiej ręki,

Przypodniesiona, jak kielich ów męki (VI, $\left.1^{7}\right)$.

Emigracja staje się misją, ale na wzór konkwisty:

Kraje bogate są, złota w nich - siła,

Tylko że naród czarny i dziki,

To przez to, nas tam chcą mieć, katoliki (I, II $\left.{ }^{8}\right)$.

Nic też dziwnego, że stosunek do Innego odbiegał będzie od zasad wyznawanej wiary:

Kolonia tutaj! Nie chamy, Murzyny (...)

Już świta... Pędzim przed się tę hołotę

Czarną, jak właśnie barany z kiermasza

W Łukowie, w Miedznej, aboli w Wołyni?

Tak radykalne postawy nie były jedynymi i trzeba pamiętać, że przywołane są tu z nacechowanej tendencyjnie epopei emigracyjnego oraz kolonizacyjnego fiaska, która mimo swych wartości literackich i dokumentalnych stała się fiaskiem epopei. Jednakże istniały i muszą być brane pod uwagę, gdy próbujemy zrozumieć emigrację jako złożony proces społeczny i kulturowy, uwikłany w relacje zależności i konfrontacji postaw wobec Innego, określonych przez czynniki natury politycznej i różnice kulturowe, gdzie emigracja jako adopcja cudzej ziemi w celu jej kultywacji (a nie eksploatacji) wiąże się z wejściem w rolę kolonizatora (kolonisty), będąc zarazem poddana kolonialnej w sensie antropofagicznej formuły brazylijskiego modernizmu strategii przyjmującego państwa i jego kultury. Krytyka postkolonialna, szczególnie wrażliwa na te właśnie aspekty dzieł literackich i kulturowych świadectw, to naturalny sprzymierzeniec badań procesów migracyjnych, nie tylko z perspektywy emigracji i kolonizacji, ale we wzajemnym tych perspektyw sprzężeniu.

\footnotetext{
7 Tamże, s. 427.

8 Tamże, s. 21.

9 Tamże, s. 230, 257.
} 